\title{
Lif takviyeli pirinç kabuğu külü ikameli beyaz çimentolu harçların bazı mekanik özelliklerinin incelenmesi
}

\author{
Yurdakul AYGÖRMEZ* \\ Yıldız Teknik Üniversitesi İşaat Fak. Inşaat Müh. Böl., Davutpaşa kampüsü, İstanbul \\ Geliş Tarihi (Received Date): 22.10.2020 \\ Kabul Tarihi (Accepted Date): 23.12.2020
}

$\ddot{O} z$

Bu çalışmada Beyaz Çimento (PC CEM I 52.5 R) ile pirinç kabuğu külünün ikamesi (ă̆ırlıkça \%5, \%15 ve \%25 oranında) araştırılmıştır. Bu şekilde $\mathrm{CO}_{2}$ salınımı azaltılması ve maliyetin düşürülmesi amaçlanırken mekanik özellikler de araştırılmıştır. Ayrıca en yüksek dayanıma sahip \%15 oranında pirinç kabuğu külü ikameli çimento harçlarında polivinil alkol (PVA) ve bazalt (B) lifleri hacimce \%0.5, \%1 ve \%1.5 oranında kullanılmıştır. Bu şekilde üretilen 10 serinin 7 ve 28 günlük basınç ve eğilme dayanımı sonuçları incelenmiştir. Ayrıca yüksek sıcaklık etkisini görmek için 200, 400 ve $600{ }^{\circ} \mathrm{C}$ sıcaklıklar uygulanmıştır. Yüksek sıcaklık sonrası basınç ve eğilme dayanımı ve ă̆ırlık kayıpları bulunurken oluşan görsel durum incelenmiştir. Ayrıca yüksek sicaklı öncesi ve sonrasi Mikro Bilgisayarl Tomografi (Micro-CT) analizleri yapılmıştır. 7 ve 28 günlük sonuçlar incelendiğinde \%15 oranında pirinç kabuğu külü ikamesine kadar dayanım artışı görülmüş̧ür. Puzolanik özellik gösteren pirinç kabuğu külü bu oranda kullanılmasıyla çimentolu sistemlerde oluşturduğu fiziko-kimyasal etkisi sebebi ile dayanım özellikleri üzerinde artış oluşturmaktadır. Yüksek $\mathrm{SiO}_{2}+\mathrm{Al}_{2} \mathrm{O}_{3}$ oranına (\%81.27) sahip puzolan içeren çimento harcında uzun dönemli dayanım da artış göstermektedir. Kısa dönemde ise doğal puzolanın özgül yüzey alanı (incelik) dayanım açısında birinci derecede etkili olmaktadır. Daha yüksek oranda kullanılmasıyla ise işlenebilirliğin düşmesi mekanik özellikleri azaltmıştır. Liflerin kullanılmasıyla eğilme dayanımında sürekli artış olmuştur. Basınç dayanımı sonuçları ise \%1 oranina kadar artış gösterirken daha yüksek oranda kümelenme nedeniyle azalış olmuştur. Yüksek sıcaklıklardan sonra tahribatlar nedeniyle dayanım değerlerinde düşüs oluşmuş fakat kayıplara rağmen çimento harçları stabilitesini korumuştur.

Anahtar kelimeler: Beyaz çimento, pirinç kabuğu külü, PVA lifi, bazalt lifi, yüksek sicaklık, micro-CT.

\footnotetext{
*Yurdakul AYGÖRMEZ, aygormez@yildiz.edu.tr, http://orcid.org/0000-0001-7405-2450
} 


\title{
Investigation of some mechanical properties of fiber-reinforced rice husk ash substituted white cement mortars
}

\begin{abstract}
In this study, the substitution of rice husk ash (5\%, $15 \%$ and $25 \%$ by weight) with White Cement (PC CEM I $52.5 \mathrm{R}$ ) was investigated. In this way, it is aimed to reduce $\mathrm{CO}_{2}$ emission and decrease the cost, while the mechanical properties have also been investigated. In addition, polyvinyl alcohol (PVA) and basalt (B) fibers were used at the rate of $0.5 \%, 1 \%$ and $1.5 \%$ by volume in the cement mortar with $15 \%$ rice husk ash substitution, which has the highest strength. The 7 and 28 days compressive and flexural strength results of 10 series produced in this way were examined. In addition, temperatures of 200, 400 and $600{ }^{\circ} \mathrm{C}$ were applied to see the high temperature effect. While determining the compressive and flexural strengths and weight loss after high temperature, the resulting visual situation was examined. In addition, Micro-Computed Tomography (Micro-CT) analyzes were performed before and after high temperature. When the results of 7 and 28 days were examined, an increase in strength was observed up to $15 \%$ rice husk ash substitution. The use of pozzolanic rice husk ash at this rate increases the strength properties due to the physico-chemical effect it creates in cement systems. Long-term strength also increases in cement mortar containing pozzolan with high $\mathrm{SiO}_{2}+\mathrm{Al}_{2} \mathrm{O}_{3}$ ratio $(81.27 \%)$. In the short term, the specific surface area (fineness) of the natural pozzolan is primarily effective in terms of strength. With a higher rate of use, the decrease in workability decreased the mechanical properties. There has been a continuous increase in flexural strength with the use of fibers. While the compressive strength results increased by up to 1\%, there was a decrease due to higher rate of clustering. After high temperatures, there was a decrease in the strength values due to destructions, but the cement mortar stability was preserved despite the losses.
\end{abstract}

Keywords: White cement, rice husk ash, PVA fiber, basalt fiber, high-temperature, micro-CT.

\section{Giriş}

Beton, dünyadaki her insan için yılda bir metreküpten fazla olmak üzere dünyada en çok üretilen malzemedir [1]. Tipik bir beton, esasen trikalsiyum silikat ve dikalsiyum silikat fazlarından (sırasıyla alit ve belit olarak bilinir) oluşan hidratlı Geleneksel Portland Çimentosuyla (GPÇ) beraber kabaca hacimce \%70 agrega içerir [2]. Suya maruz kaldıklarında kalsiyum silikatlar, betondaki basınç dayanımının kaynağı olan kohezif bir faz olan kalsiyum hidroksit ve kalsiyum silikat hidrat (CSH) jeli oluşturur [3-4]. Beyaz Çimento aynı zamanda bir Portland Çimentosudur ve üretim süreci normal (ASTM Tip I veya II) gri çimentoya oldukça benzerdir ve renk hariç, esasen gri çimento ile aynı özelliklere sahiptir. Bu durum, çimentoya gri rengini veren maddeler olan ihmal edilebilir miktarlarda demir oksit (ağırlıkça yüzde 0,5 ten fazla olmayan) ve mangan oksit içeren hammaddelerin dikkatli bir şekilde seçilmesiyle elde edilir. Gerekli alümina içeriğini elde etmek için genellikle boksit (alüminyum oksit) gereklidir. Demir oksit, yanma işleminde bir akı görevi gördüğünden, Beyaz Çimento üretim sürecinde bu işlevi yerine getirmek için bazen sodyum alüminyum florür eklenir. Ayrıca, kömür külü ile kirlenmeyi önlemek için yakma sürecinde pülverize kömürün 
yerine genellikle yağ yakıtı kullanılır. Çimento klinkerinin öğütülmesi sürecinde demir kirletmesini önlemek için özel bilyalı değirmenler kullanılmalıdır [5]. Özellikle mimari beton uygulamaları açısından vazgeçilmez sayılan Beyaz Portland Çimentosu, yüksek saflıkta hammaddeden üretildiği için minimum $\% 85$ beyazlığa sahiptir. Beyaz çimentonun uygulamaları arasında prekast perde duvarlar ve cephe panelleri, dökme mozaik yüzeyler, sıva, çimento boyası, fayans harcı ve dekoratif beton bulunmaktadır. Renklendirici pigmentler ile başarılı karışımların hazırlanmasını sağlar. Ayrıca uygun formların kullanılmasıyla yüksek incelikte istenilen beton yüzeyler elde edilebilir. Daha yüksek hammadde maliyeti ve üretim prosedürlerindeki değişiklikler, Beyaz Çimentonun fiyatını Geleneksel Portland Çimentosunun fiyatından önemli ölçüde daha yüksek yapmaktadır [6]. Ayrıca çimento kullanımı ile sera gazı emisyonu önemli ölçüde artmaktadır. Bu şekilde oluşan emisyonların önümüzdeki yıllarda artacağı bir gerçektir. Böylelikle küresel ısınma endeksleri de etkilenmektedir. Bu durumda ileride inşaat alanında yoğun beton kullanımı, sürdürülebilirlik ile ilgili adımların atılmasını gerekli kılmaktadır. Sürdürülebilirlik kavramının sağlanması için betonda farklı yan ürünlerin kullanılması önemli bir avantaj sağlar ve çevresel olumsuz etkileri azaltır [78].

Yüksek reaktif ve amorf silika içeren pirinç kabuğu külü çimento yerine puzolanik malzeme olarak kullanılma potansiyeli büyük olan yan ürünlerden biri olarak kabul edilmektedir. Pirinç kabuğu külü, pirinç kabuğunun kontrollü sıcaklıklarda yakılmasıyla üretilir ve Portland Çimentosuna benzer veya daha ince partiküller halinde toz haline getirilir. Üretilen küllerin kalitesi pirinç kabuğuna uygulanan öğütme ve çapaklama işlemine bağlıdır. Yıllar boyunca pirinç kabuğu külü, inşaat sektörü de dahil olmak üzere birçok alanda birçok uygulamada kullanılmıştır. Bazı araştırma sonuçları, Portland Çimentosunun kısmi ikamesi olarak \%10'a kadar pirinç kabuğu külü kullanılmasının, betonda maksimum mukavemet kazanımına [9-13] ve hidroklorik ve sülfürik asit saldırılarına karşı direnci artırmasına [14-15] yol açtığını ortaya koymuştur. Bu arada, Van ve ark. [16], Portland Çimentosunun pirinç kabuğu külü ile değiştirilme yüzdesi arttıkça, kuruma ve kendiliğinden oluşan büzülme gerilemelerinin yanı sıra karbonatlaşma derinliğinin de arttığını göstermiştir. Çok ince parçacıklara öğütülürse, pirinç kabuğu külü priz süresini kısaltır ve kontrol karışımına kıyasla çimentonun mikro yapısını yoğunlaştırır [17-18].

Bazalt ve Polivinil Alkol (PVA), lif takviyeli beton araştırmalarında kullanılmıştır. Beton ve harç örneklerinde polivinil alkol (PVA) ve bazalt liflerinin etkisi incelendiğinde, mekanik özelliklerde pozitif bir artış ürettikleri görülmüştür [19]. Yapılan çalışmalara göre bazalt, çimento hamuruyla daha iyi bir kimyasal bağ kurar ve çatlama mukavemetini artırırken, PVA daha iyi lif köprüleme kapasitesine sahiptir ve daha iyi çatlak sonrası davranış gösterir [20]. Bazalt lifi, normal dayanımlı betonda hem basınç hem de eğilme dayanımını artırır [21]. Bazalt lifi, lif içeriği ve uzunluğundaki artışla tokluk indeksini, eğilme ve çekme mukavemetini artırırken [22], yüksek mukavemetli betonda basınç mukavemeti önemli ölçüde artırmaz [23]. PVA lifi kullanılması durumunda, lif miktarındaki artışla birlikte basınç dayanımı ve elastisite modülü azalır ancak yarmada çekme dayanımı artar [24]. Noushini, Samali ve Vessalas [25], farklı lif içeriğgi, uzunluğu ve en-boy oranı olan PVA lif takviyeli betonu araştırmıştır. Sonuçlar, PVA lifinin tokluğu ve eğilme dayanımını artırdığını göstermiştir. Annam [26] ayrıca PVA'nın basınç dayanımını azalttığını ancak yarmada çekme dayanımını arttırdığ 1 sonucuna varmıştır. 
Farklı doku ve renk özellikleri taşıyan çimentolu kompozitlerin üretiminde ve özellikle mimari beton üretiminde kullanım potansiyeline sahip yüksek dayanımlı Beyaz Çimentoya yoğun ihtiyaç duyulmaktadır. Portland Çimento yerine ikame malzemelerin kullanıldığı çok sayıda çalışma mevcuttur. Bu çalışmada diğer çalışmalardan farklı olarak Beyaz Çimento (PC CEM I 52.5 R) kullanılmıştır. Beyaz Çimento kullanımına ek olarak, ikame olarak pirinç kabuğu külü kullanılmış ve maliyet, çevre ve mukavemet açısından optimum karışım araştırılmıştır. $\mathrm{Bu}$ sayede çimento teknolojisindeki ilerlemeler ile üretimine başlanan yüksek dayanımlı Beyaz Çimentolu kompozitlerde pirinç kabuğu külünün kullanımı ile mekanik ve durabilite özelliklerinin etkisi araştırılması amaçlanmıştır. Bu çalışmada pirinç kabuğu külü ağırlıkça üç farklı oranda (\%5, \%15 ve \%25) ikame edilmiştir. Ayrıca en yüksek dayanıma sahip numunede üç farklı oranda (hacimce \%0.5, \%1 ve \%1.5) PVA ve bazalt lifi kullanılmıştır. İlk karışım \%100 Beyaz Çimento ile üretilen kontrol karışımı olmak üzere toplam 10 seri hazırlanmıştır. Hazırlanan karışımların 7, 28 ve 90 günlük basınç ve eğilme dayanımları belirlenmiştir. Aynı zamanda hazırlanan 10 serinin yükssek sıcaklık etkisi karşısında davranışını görmek için 200, 400 ve $600{ }^{\circ} \mathrm{C}$ yüksek sicaklıklar uygulanmıştır. Yüksek sıcaklık testinden sonra basınç dayanımı, eğilme dayanımı, ağırlık kaybı sonuçları incelenmiştir. Ayrıca yüksek sıcaklık etkisiyle görsel inceleme ve Micro-CT analizi yapılmıştır.

\section{Deneysel çalışmalar}

\subsection{Malzemeler}

$\mathrm{Bu}$ çalışmada PC CEM I 52.5 R tipi yüksek performanslı çimento kullanılmıştır. Çimento, Çimsa Çimento Sanayi ve Ticaret A.Ş.'den temin edilmiştir. Özgül ağırlık, başlangıç priz süresi ve bitiş priz süresi sırasıyla 3.06, 100 dakika ve 130 dakikadır. Spesifik yüzey alanı (Blaine) $4600 \mathrm{~cm}^{2} / g r$ 'dır. Çimentonun kimyasal özellikleri Tablo 1'de gösterilmektedir. Beyaz Çimento BÇ kısaltması ile ifade edilmiştir. Pirinç kabuğu külü, Yetiş Çeltik Fabrikası'ndan (Trakya-İpsala) temin edilmiştir. Spesifik yüzey alanı (Blaine) $6710 \mathrm{~cm}^{2} / g r ' d ı r$. Pirinç kabuklarının fabrikada özel olarak tasarlanmış fırında $900^{\circ} \mathrm{C}$ sıcaklıkta yakılmasıyla pirinç kabuğu külü üretilir. Pirinç kabuğu, Türkiye'nin hemen hemen her yerinde üretilen çeltik kabuklarından üretilmektedir. Pirinç kabuğu külünün de kimyasal özellikleri Tablo 2'de gösterilmektedir.

Tablo 1. Beyaz Çimentonun kimyasal bileşimi.

\begin{tabular}{|c|c|c|c|c|c|c|c|c|c|c|c|}
\hline Malzeme & $\mathrm{SiO}_{2}$ & $\mathrm{Al}_{2} \mathrm{O}_{3}$ & $\mathrm{Fe}_{2} \mathrm{O}_{3}$ & $\mathrm{~K}_{2} \mathrm{O}$ & $\mathrm{CaO}$ & $\mathrm{MgO}$ & $\mathrm{K}_{2} \mathrm{O}$ & $\mathrm{Na}_{2} \mathrm{O}$ & $\mathrm{SO}_{3}$ & $\mathrm{CaO}$ & $\mathrm{K} . \mathrm{K}$. \\
\hline $\mathrm{BC}$ & 21.60 & 4.05 & 0.26 & 0.35 & 65.7 & 1.30 & 0.35 & 0.30 & 3.30 & 1.60 & 3.20 \\
\hline
\end{tabular}

Tablo 2. Pirinç Kabuğu Külünün kimyasal bileşimi.

\begin{tabular}{|c|c|c|c|c|c|c|c|c|}
\hline Malzeme & $\mathrm{Nem}$ & $\mathrm{Kül}$ & $\mathrm{SiO}_{2}$ & $\mathrm{Fe}_{2} \mathrm{O}_{3}$ & $\mathrm{CaO}$ & $\mathrm{MgO}$ & $\mathrm{Al}_{2} \mathrm{O}_{3}$ & Karbon \\
\hline $\begin{array}{c}\text { Pirinç } \\
\text { Kabuğu } \\
\text { Külü }\end{array}$ & 0.8 & 88.0 & 80.8 & 0.43 & 1.94 & 0.95 & 0.47 & 6.58 \\
\hline
\end{tabular}


Tablo 2 incelendiğinde oksit bileşenlerin numunede \%84.6 oranında olduğu görülürken numunenin kül içeriği \%88'e karşıllk gelmektedir. $\mathrm{Bu}$ durum $900^{\circ} \mathrm{C}$ 'de yakılma işleminden dolayı silis miktarının bir kısmında kristalleşme oluşmasından kaynaklanmaktadır. Detaylı kül analizi yapılması durumunda yaklaşık \%4.0 diğer oksitler, \%84.0 silis, \%0.8 nem ve \%11.2 oranında yanmamış karbon içeriği görülmektedir [27]. Bu çalışmada iki farklı lif (Polivinil alkol ve bazalt) kullanılmıştır. PVA ve B, sırasıyla polivinil alkol ve bazalt liflerinin kısaltmaları olarak kullanılmıştır. Liflerin özellikleri Tablo 3 'te verilmiştir. Ayrıca bu çalışmada, agrega olarak Trakya Limak Çimento Fabrikasından temin edilen standart kum (BS EN 196-1'e uygun) kullanılmıştır.

Tablo 3. Liflerin özellikleri.

\begin{tabular}{|c|c|c|c|c|}
\hline Lif Tipi & Uzunluk $(\mathrm{mm})$ & Çap $(\mu \mathrm{m})$ & Özgül Ağırlık & $\begin{array}{c}\text { Çekme } \\
\text { Dayanımı } \\
(\mathrm{MPa})\end{array}$ \\
\hline PVA & 8 & 39 & 1.30 & 1620 \\
\hline B & 12 & 20 & 2.73 & 4100 \\
\hline
\end{tabular}

\subsection{Harç üretimi}

Karışım hazırlanırken önce kuru karışım hazırlanmıştır. Kuru karışım için bağlayıcı malzemeler ve agregalar karıştırılmıştır. Standart kum/bağlayıcı oranı 2.75:1 olarak belirlenmiştir. Kuru karışım, bir mikser matkap kullanılarak 1 dakika boyunca karıştırılmıştır. Su/bağlayıcı oranı tüm karışımlarda 0,5 sabit oranında kullanılmıştır. Kuru karışıma su ilave edildikten sonra karıştırmaya 3 dakika daha devam edilmiştir. Daha sonra hazırlanan karışım kalıplara yerleştirilmiş ve vibrasyon uygulanmıştır. Harç

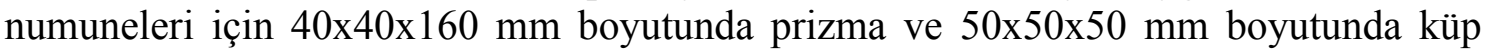
kalıplar kullanılmıştır. Toplam 10 seri hazırlanmış ve ilk seride sadece Beyaz Çimento ve standart kum kullanılmıştır. 2., 3. ve 4. seride sırasıyla pirinç kabuğu külü ağırlıkça $\% 5, \% 15$ ve $\% 25$ oranında katılmıştır. Diğer serilerde ise 3 . Seriye PVA ve B lifleri sırasıyla \%0.5, \%1 ve \%1.5 hacim oranında katılmıştır. Hazırlanan karışımların detayları Tablo 4'te verilmiştir. Dökümden sonra numuneler laboratuvar koşullarında [23 $\pm 2{ }^{\circ} \mathrm{C}$ sıcaklık ve $\% 50 \pm 4$ bağıl nem] 24 saat kurumaya bırakılmıştır. Daha sonra 28 gün suda kür yapılmıştır.

Tablo 4. Numunelerin karıştırma yüzdeleri (\%).

\begin{tabular}{|c|c|c|c|c|}
\hline $\begin{array}{c}\text { Karış1m } \\
\text { Serileri }\end{array}$ & $\begin{array}{c}\text { Beyaz } \\
\text { Çimento }\end{array}$ & $\begin{array}{c}\text { Pirinç Kabuğu } \\
\text { Külü }\end{array}$ & PVA & B \\
\hline Kontrol (1) & 100 & 0 & - & - \\
\hline PK5 (2) & 95 & 5 & - & - \\
\hline PK15 (3) & 85 & 15 & - & - \\
\hline PK25 (4) & 75 & 25 & - & - \\
\hline 0.5PVA (5) & 85 & 15 & 0.5 & - \\
\hline 1PVA (6) & 85 & 15 & 1 & - \\
\hline 1.5PVA (7) & 85 & 15 & 1.5 & 0.5 \\
\hline 0.5B (8) & 85 & 15 & - & 1 \\
\hline 1B (9) & 85 & 15 & - & 1.5 \\
\hline 1.5B (10) & 85 & 15 & - & \\
\hline
\end{tabular}




\subsection{Test yöntemi}

Numunelerin ilk olarak 7 ve 28 günlük basınç ve eğilme dayanımlarına bakılmıştır. Basınç dayanımı için 50x50x50 mm'lik küp numuneler kullanılırken, eğilme dayanımı için 40x40x160 mm'lik prizma numuneleri kullanılmıştır. Basınç dayanımı testi ASTM C 109'e göre [28] yapılırken eğilme dayanımı testi ASTM C 348'e göre [29] yapılmıştır. Her test için üçer numune hazırlanmış olup sonuç için üç numunenin ortalaması alınmıştır. 28 günün sonunda numunelere 200,400 , ve $600{ }^{\circ} \mathrm{C}$ sicaklıklar uygulanmıştır. Numuneler, yüksek sıcaklıktan önce $105^{\circ} \mathrm{C}$ 'de 1 gün tutulmuştur. Yüksek sıcaklık fırınının sıcaklık artış hızı $5^{\circ} \mathrm{C} /$ dakika olarak ayarlanmıştır. Hedef sıcaklığa ulaştıktan sonra numuneler bu sicaklıkta 1 saat tutulmuştur. Numuneler test sonrası ani şoktan kurtulmak için bir süre kapağı açık olarak fırında bekletilmiştir. Yüksek sıcaklıktan önce ve sonra numunelerde ağırlık kaybı bulunmuştur. Ayrıca yüksek sıcaklık testinden sonra basınç ve eğilme sonuçları bulunmuştur. Test sonrasında numunelerin görsel incelemesi ve Micro-CT analizi de yapılmıştır.

\section{Sonuçlar ve tartışma}

\subsection{Dayanım Sonuçları}

Bu çalışmada hazırlanan 10 serinin 7 ve 28 günlük basınç ve eğilme dayanımları Şekil 1-2'de gösterilmektedir. Çalışmada kontrol karışımına göre üç farklı oranda pirinç kabuğu külü kullanılması durumunda $\% 5$ ve $\% 15$ oranlarında kontrol karışıma göre dayanım artışı görülmüştür.

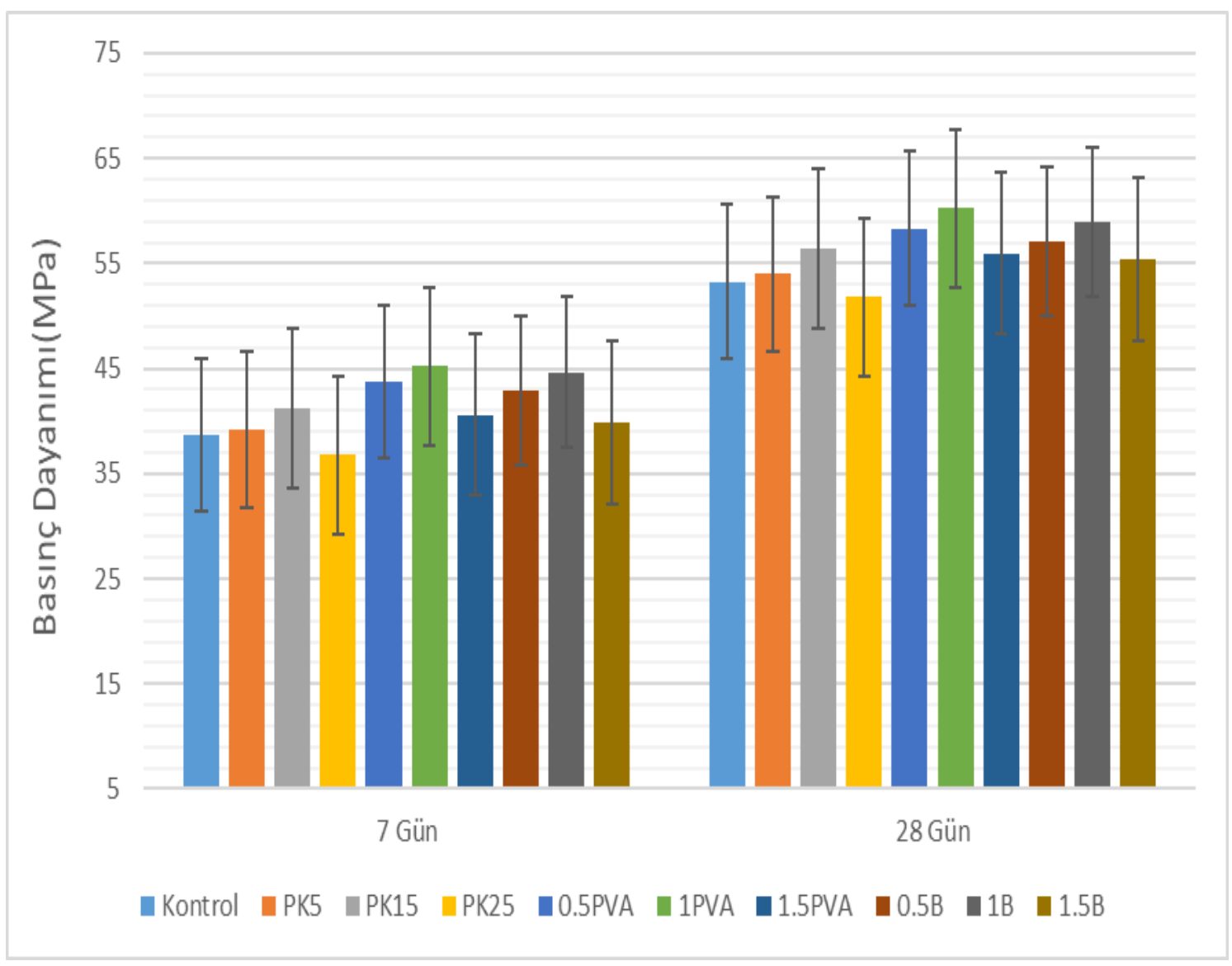

Şekil 1. Basınç dayanımı sonuçları. 


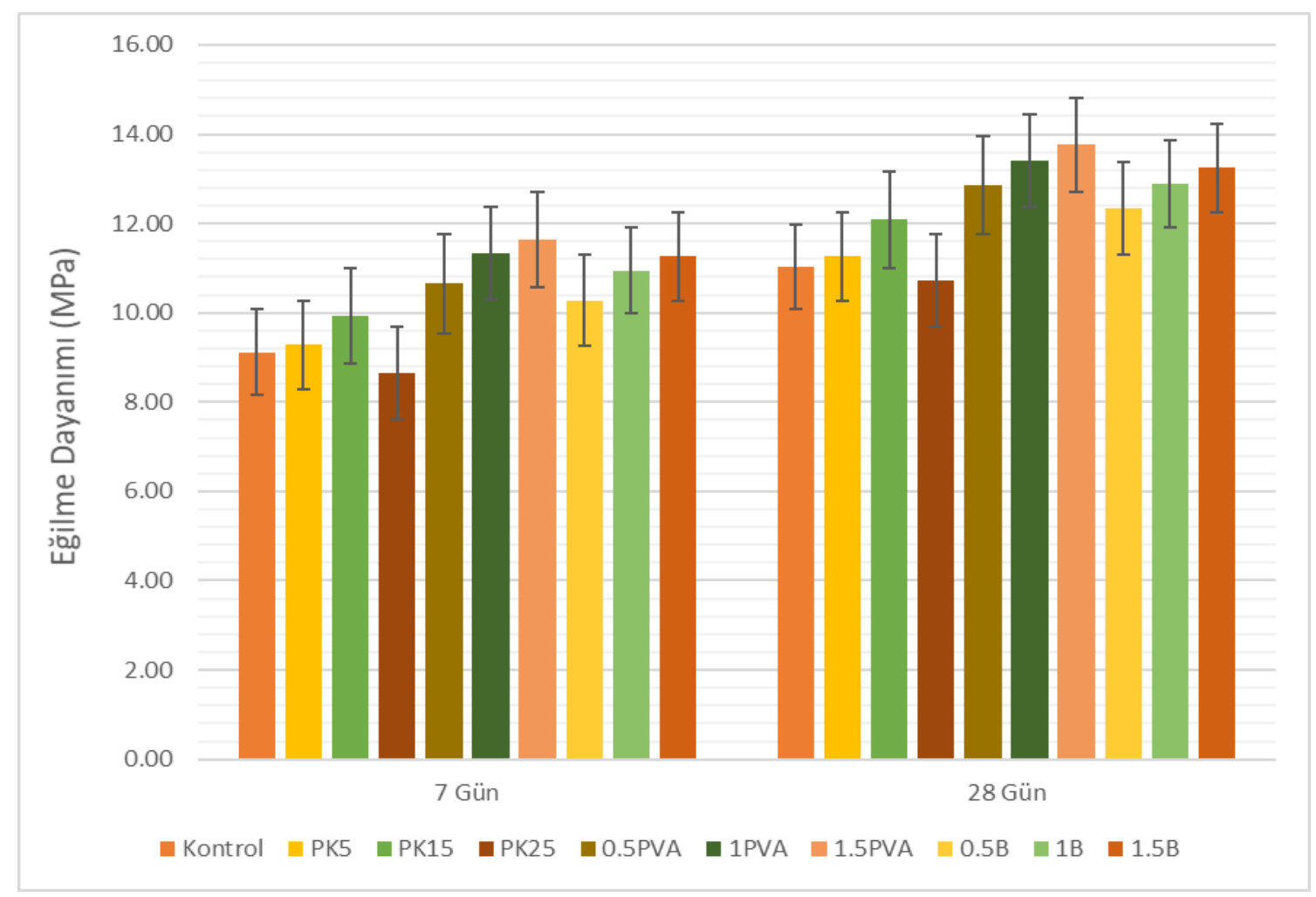

Şekil 2. Eğilme dayanımı sonuçları.

Bunun nedeni, pirinç kabuğu külünün daha yüksek inceliğinin $\mathrm{Ca}(\mathrm{OH})_{2}$ ile reaksiyonu artırarak daha fazla kalsiyum silikat hidrat (C-S-H) üretilmesini sağlaması ve buna ek olarak daha yüksek basınç dayanımı ile sonuçlanan ince pirinç kabuğu külü partiküllerinin mikro dolgu olarak hareket ederek ve çimento hamurunun gözenek yapısını güçlendirerek dayanım gelişimine katkı sağlamasıdır [30]. \%5 ikame kullanıldığında mevcut olan pirinç kabuğu külü miktarının dayanımı önemli ölçüde artırmak için yeterli olmadığı fark edilmiştir. \%5 pirinç kabuğu külü ilavesinden elde edilen mevcut silika, hidrasyon işleminden salınan C-H'nın sadece küçük bir kısmı ile reaksiyona girmiş ve bu nedenle, puzolanik reaksiyondan salınan C-S-H nispeten sınırlı olmuştur [31]. Dayanım, \%15 ikame oranında daha yüksek olmuştur. Bu durum, pirinç kabuğu külünden gelen mevcut silikanın puzolanik reaksiyonu ve hidrasyon işleminden elde edilebilen $\mathrm{CH}$ miktarı ve ayrıca ince pirinç kabuğu külünden dolayı mikro-dolgu etkisinden kaynaklanmaktadır [32]. Pirinç kabuğu külü, Beyaz Çimentonun \%25'i oranında değiştirildiğinde, basınç dayanımı kontrol karışımına göre daha düşük olmuştur. $\mathrm{Bu}$ durum artan oranla beraber işlenebilirliğin düşmesinden kaynaklanmaktadır. Ayrıca pirinç kabuğu külü ikame seviyesinin artırılması ile dayanımdaki azalma, çimento miktarındaki azalmadan kaynaklanmaktadır ve bunun bir sonucu olarak, hidratasyon işlemi nedeniyle açığa çıkan $\mathrm{CH}$ miktarı, ikameden elde edilen mevcut tüm silika ile reaksiyona girmek için yeterli değildir. Pirinç kabuğu ve dolayısıyla silika, inert malzeme olarak hareket ederek dayanım gelişimine katkıda bulunmamaktadır [33]. Lifsiz serilerde 7 günlük basınç dayanımı sonuçları incelendiğinde en yüksek sonuç 41.23 MPa ile PK15'te elde edilmiştir. 28 günlük basınç dayanımı sonuçları incelendiğinde en yüksek sonuç yine PK15'te $56.39 \mathrm{MPa}$ olarak elde edilmiştir. 7 ve 28 günün sonunda en düşük basınç dayanımı sonuçları PK25'te sirasiyla 36.81 MPa ve 51.84 MPa olarak elde edilmiştir. Yine lifsiz serilerde 7 günlük eğilme dayanımı sonuçları incelendiğinde en yüksek sonuç $9.94 \mathrm{MPa}$ ile 
PK15'te elde edilmiştir. 28 günlük eğilme dayanımı sonuçları incelendiğinde en yüksek sonuç yine PK15'te $12.08 \mathrm{MPa}$ olarak elde edilmiştir. 7 ve 28 günün sonunda en düşük eğilme dayanımı sonuçları PK25'te sırasıyla $8.65 \mathrm{MPa}$ ve $10.72 \mathrm{MPa}$ olarak elde edilmiştir.

Lif katkı maddesinin basınç dayanımı sonuçlarını \%1 oranında kullanılması durumunda arttırdığı, \%1.5 oranında kullanılması durumunda ise basınç dayanımı sonuçlarını düşürdüğü görülmüştür. Buradaki basınç dayanımındaki artış, esas olarak liflerin ilerleyen çatlaklarla etkileşiminden kaynaklanmaktadır. Basınç yükü arttıkça yanal gerilim artar ve böylece çatlaklar ilerlemeye başlar. İlerleyen çatlak, takip ettiği yola dik çekme gerilmeleri ile bir life yaklaşırken matris-lif arayüzünde sıyrılma oluşturur. İlerleyen çatlak arayüze ulaştığında, lif, mevcut lif sıyrılması nedeniyle bir kütleştirme süreciyle karşılaşmıştır. Kütleştirme işlemi sayesinde çatlak ucundaki gerilme konsantrasyonu azaltılır ve çatlağın ilerlemesi engellenir ve hatta yolu değiştirilir. Çatlağın bu şekilde kütleştirilmesi, bloke edilmesi ve daha fazla saptırılması, harç numunelerinin ilave basınç yüküne dayanmasına ve böylece lif olmayan numunelere kıyasla basınç dayanımının artmasına izin vermiştir. Ayrıca, bu liflerin karışım suyu içinde uygun bir şekilde dağıldığı ve kendilerini daha iyi dağıtabildikleri ve böylece basınç dayanımını artırabildikleri düşünülmektedir. Yani, polimerik lifler matris içinde iyi dağıldığından, uygulanan gerilmelerin taşınmasına yardımcı olurlar. Böylece, lifler ve harçlar, lif-matris arayüzündeki gerilme aktarım mekanizmasıyla gelen basınç yükünü dağıtabilir. Diğer bir olasılık da, bu liflerin kompozitlerin plastisitesini artırarak gerilme altında kırılmadan akmalarıdır [34]. PVA ve bazalt liflerinin, sistematik olarak performansı arttırdığı görülmüştür. Lifli malzemelerde kristal fazların ince dağılımı ve homojen yapısı, mekanik özelliklerde iyileşmeyi arttırmıştır. $\mathrm{P}_{2} \mathrm{O}_{5}, \mathrm{TiO}_{2}$ veya $\mathrm{ZrO}_{2}$ gibi çekirdekleştirici bir ajanın eklenmesi mikro yapıyı güçlendirmiştir. Ayrıca bazalt lifleri, bazaltik kayaların erimesi sırasında kendiliğinden $\mathrm{Fe}_{3} \mathrm{O}_{4}$ gibi doğal bir çekirdek oluşturucu üreterek önemli bir avantaj sağlamıştır [35]. Sonuçlar incelendiğinde, PVA lifleri, çimento matrisiyle iyi bağlanmaları ve daha yüksek çekme dayanımı özellikleri nedeniyle B liflerinden daha iyi yapısal performans sağladığı görülmüştür. Bu çalışma, PVA liflerinin mukavemeti bazalt liflere göre daha fazla arttırdığı önceki çalışmalarla uyumludur [36-37]. Liflerin kullanım oranı \%1.5 olunca basınç dayanımı azalmıştır. $\mathrm{Bu}$ azalmanın nedenleri, liflerin düşük yoğunluğu ve kümelenmesidir. $\mathrm{Bu}$, basınç dayanımında bir azalmaya neden olur. Ayrıca kümelenme ile işlenebilirliğin azaldığı gözlenmiştir [38]. Kompozitlere liflerin eklenmesi çatlakların durma yeteneğini, yani çatlama direncini önemli ölçüde artırır ve mikro çatlakların makroskopik seviyesini geciktirir [36]. Çatlak yüzeyini geçen lif sayısındaki artış, çatlak ilerlemesini azalttığı için harcın eğilme dayanımının artmasının en önemli nedenlerinden biridir. Yükleme sırasında, mikro çatlaklar birbirine bağlanır ve daha büyük çatlaklar oluşturur, lifler ise kırılma yüzeyinin her iki tarafını birbirine bağlar ve köprü görevi görür ve pik yükü arttırır. Bu durum, pik yükten sonra yük taşıma kapasitesinde bir gelişme ve eğilme tokluğunda bir artış anlamına gelir. Lif içeriği oranı ne kadar yüksekse, çatlamadan sonra tepkideki artış o kadar büyük olur. $\mathrm{Bu}$ nedenlerle, lif oranı arttıkça, eğilme dayanımı sonuçları artmıştır [39]. Liflerin yüksek elastisite modülü, matris ile daha iyi bir bağlanma derecesi ve çatlak sonrası süneklik sağlamıştır. $\mathrm{Bu}$ durum literatür ile uyumludur [40].

\subsection{Yüksek sıcaklık testi}

28 gün sonunda yapılan yüksek sıcaklık testi sonrası basınç ve eğilme dayanımı sonuçları Şekil 3-4'te gösterilmiştir. 


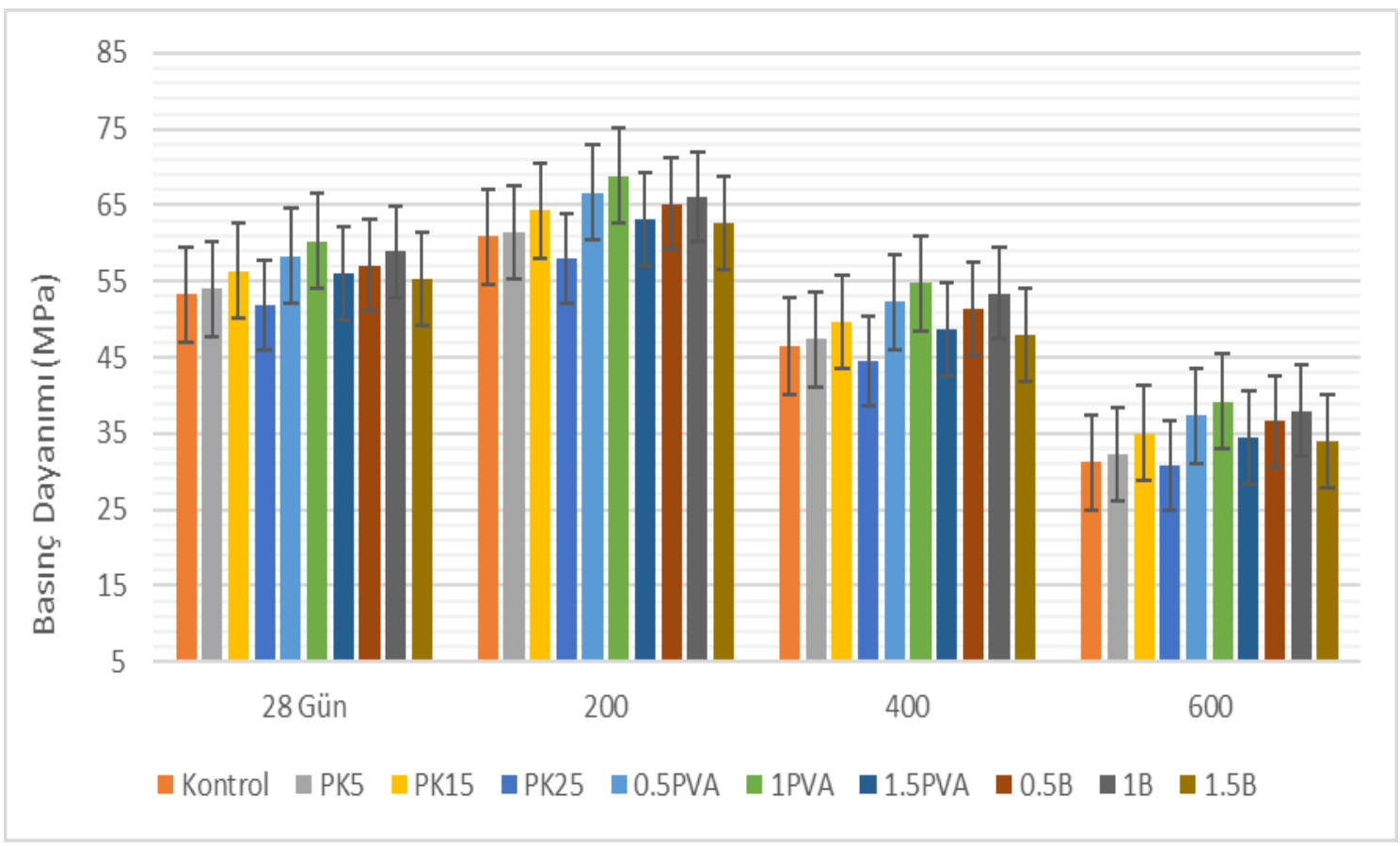

Şekil 3. Yüksek sıcaklık sonrası basınç dayanımı sonuçları.

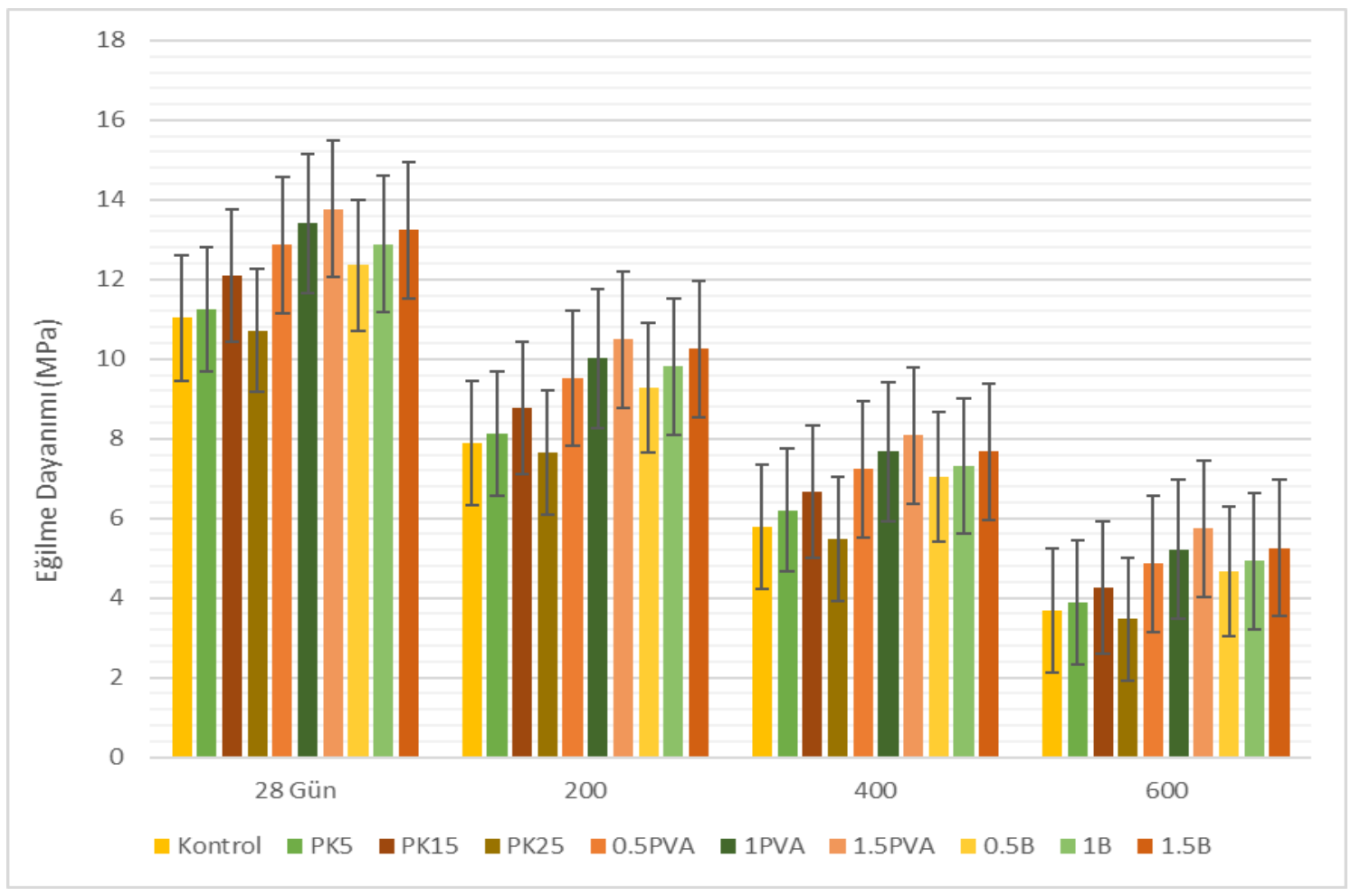

Şekil 4. Yüksek sıcaklık sonrası eğilme dayanımı sonuçları.

$200^{\circ} \mathrm{C}$ sıcaklık sonrası basınç dayanımında artış görülmüştür. Bu durumda temel neden C-S-H yapısında bozulma olmayan matriste kuruma büzülmesi oluşmasıdır. Bu büzülme etkisiyle aderansın geliştiği ve etki eden gerilmelerin azaldığ 1 görülmektedir. Ayrıca van der Waals kuvvetlerinde artışla kılcal gözeneklerin daha yakınlaşması da bu durumu artırır. Dayanım artışıı sağlayan diğer durum da hidratlanmamış çimento 
parçacıklarının hidratasyonuyla oluşur. Sıcaklık artışı hidratasyonu hızlandırarak kürün devamına katkı sağlar [41]. Basınç dayanımında oluşan bu duruma karşı eğilme dayanımında sürekli bir azalış görülür. Yüksek sıcaklık etkisine maruz kalan harçların eğilme dayanımının basınç dayanımına kıyasla daha fazla etkilendiği görülmüştür. Bu davranış, eğilme deneylerinde oluşan çekme gerilmelerinin basınç gerilmelerine kıyasla kusurları, diğer bir deyişle yüksek sıcaklıklarda oluşan mikro çatlakları daha belirgin göstermesine bağlanabilinir [42].

Kılcal gözeneklerde bulunan su $100^{\circ} \mathrm{C}$ 'den sonra dışarı çıkmaya başlar. Hidratlardaki yapısal su ve jelde adsorbe sular $250-300{ }^{\circ} \mathrm{C}$ 'den sonra buharlaşmaya başlar. Harçta oluşan büzülmeler bu sıcaklıklardan sonra önemli seviyelerine çıkar. Yapıdan çıkan sular gözeneklerde buhar basıncı oluşumunu tetikler. Ayrıca nem içeriğinin artması da bu durumu artırır. Yine bu sıcaklıklardan itibaren demir ve alümina oksit bileşenlerinde susuzluk başlar. $400^{\circ} \mathrm{C}$ sicaklık sonrası $\mathrm{Ca}(\mathrm{OH})_{2}$ 'den $\mathrm{CaO}^{\prime}$ ya dönüşümler artar ve $600^{\circ} \mathrm{C}$ sonrası C-S-H yapısında tahribatlar oluşur. Hasar mekanizması ile önemli dayanım kayıpları olmuştur [43].

Sonuçlar incelendiğinde yüksek sicaklık öncesi duruma benzer koşullar oluşmuştur. Sadece Beyaz Çimento kullanılan harç numunesine göre $\% 5$ ve $\% 15$ oranlarında pirinç kabuğu külü kullanılması durumunda dayanım sonuçları artarken \%25 oranda pirinç kabuğu külü kullanılması durumunda sonuçlar daha düşük çıkmıştır. Bu durumda pirinç kabuğu külünün ince taneli olması rol oynamıştır. Bu şekilde yüksek sıcaklık testi öncesi $\mathrm{Ca}(\mathrm{OH})_{2}$ ile reaksiyonun artması ile daha fazla kalsiyum silikat hidrat (C-SH) üretilmesi test sonrası daha üstün performansı desteklemiştir [30]. \%25 oranında işlenebilirliğin düşmesi de sonuçları olumsuz yönde etkilemiştir [33]. Lifsiz serilerde en yüksek basınç dayanımı sonuçları $\mathrm{PK} 15^{\prime}$ te $200^{\circ} \mathrm{C}$ sonrası $64.32 \mathrm{MPa}$ olurken 400 ve $600{ }^{\circ} \mathrm{C}$ sicaklıklar sonrası sirasıly $49.71 \mathrm{MPa}$ ve $35.06 \mathrm{MPa}$ olmuştur. PK25'te ise basınç dayanımı sonuçları $200^{\circ} \mathrm{C}$ sonrası $57.97 \mathrm{MPa}$ olurken 400 ve $600{ }^{\circ} \mathrm{C}$ sıcaklıklar sonrası sırasıyla 44.52 $\mathrm{MPa}$ ve $30.84 \mathrm{MPa}$ olmuştur. Yine en yüksek eğilme dayanımı sonuçları PK15'te $200^{\circ} \mathrm{C}$ sonras1 $8.78 \mathrm{MPa}$ olurken 400 ve $600{ }^{\circ} \mathrm{C}$ sicaklıklar sonrasi sırasıla 6.66 $\mathrm{MPa}$ ve 4.25 MPa olmuştur. PK25'te ise eğilme dayanımı sonuçları $200^{\circ} \mathrm{C}$ sonrasi $7.65 \mathrm{MPa}$ olurken 400 ve $600^{\circ} \mathrm{C}$ sicaklıklar sonrasi sirasiyla $5.48 \mathrm{MPa}$ ve 3.47 MPa olmuştur.

Çimentolu kompozit malzemelere lif eklemedeki ana faktör, eğilme dayanımında daha yüksek sonuçlar elde etmek ve eğilme tokluğunu arttırmaktır [44]. Polimer liflerin kompozit yapıyı güçlendirmek için kullanıldığı ve bu şekilde kullanılan liflerin eğilme dayanımını ve tokluğunu artırdığı kanıtlanmıştır [45-46]. PVA ve bazalt liflerin mekanik bütünlügü, yüksek sicaklık etkisi altında belli bir dereceye kadar korunur. Lifli malzemeler, kristal fazları, homojenlikleri ve ince dağılımları nedeniyle mekanik özellikler üzerinde iyi bir etkiye sahiptir [36]. Lif katkı maddesinin eğilme mukavemeti sonuçlarını yüksek sıcaklık sonrası arttırdığı bulunmuştur. Ancak basınç dayanımı sonuçları, \%1.5 lif kullanımında bir azalma göstermiştir. Lif katkı oranı arttıkça çimento matrisi ile lifler arasındaki bağların zayıfladığı ve matrisin olumsuz etkilendiği gözlenmiştir [47-48]. Bu durumun gözenek özelliklerini ve işlenebilirliği olumsuz etkilediği bulunmuştur. $\mathrm{Bu}$ duruma bağlı olarak basınç dayanımı kaybı olduğu düşünülmektedir. Lifli serilerde en yüksek basınç dayanımı sonucu 1PVA'da olurken en düşük basınç dayanımı sonucu 1.5B'de olmuştur. Lifli serilerde en yüksek eğilme dayanımı sonucu 1.5PVA'da olurken en düşük eğilme dayanımı sonucu $0.5 \mathrm{~B}$ 'de olmuştur. 1PVA'da $200^{\circ} \mathrm{C}$ sonrası $68.83 \mathrm{MPa}$ olurken 400 ve $600{ }^{\circ} \mathrm{C}$ sicaklıklar sonrası 
sırasıyla 54.76 MPa ve 39.24 MPa olmuştur. 1.5B'de ise basınç dayanımı sonuçları $200^{\circ} \mathrm{C}$ sonrasi $62.59 \mathrm{MPa}$ olurken 400 ve $600{ }^{\circ} \mathrm{C}$ sicakliklar sonrasi sirasiyla $47.94 \mathrm{MPa}$ ve $33.87 \mathrm{MPa}$ olmuştur. $1.5 \mathrm{PVA}$ 'da $200^{\circ} \mathrm{C}$ sonrasi $10.49 \mathrm{MPa}$ olurken 400 ve $600{ }^{\circ} \mathrm{C}$ sıcaklıklar sonrası sırasıyla $8.09 \mathrm{MPa}$ ve $5.74 \mathrm{MPa}$ olmuştur. $0.5 \mathrm{~B}$ 'de ise eğilme dayanımı sonuçları $200^{\circ} \mathrm{C}$ sonrası $9.27 \mathrm{MPa}$ olurken 400 ve $600{ }^{\circ} \mathrm{C}$ sıcaklıklar sonrası sırasıyla $7.05 \mathrm{MPa}$ ve $4.67 \mathrm{MPa}$ olmuştur. 28 gün sonunda yapılan yüksek sicaklık testine göre ağırlık kayıpları Şekil 5 'te gösterilmiştir.

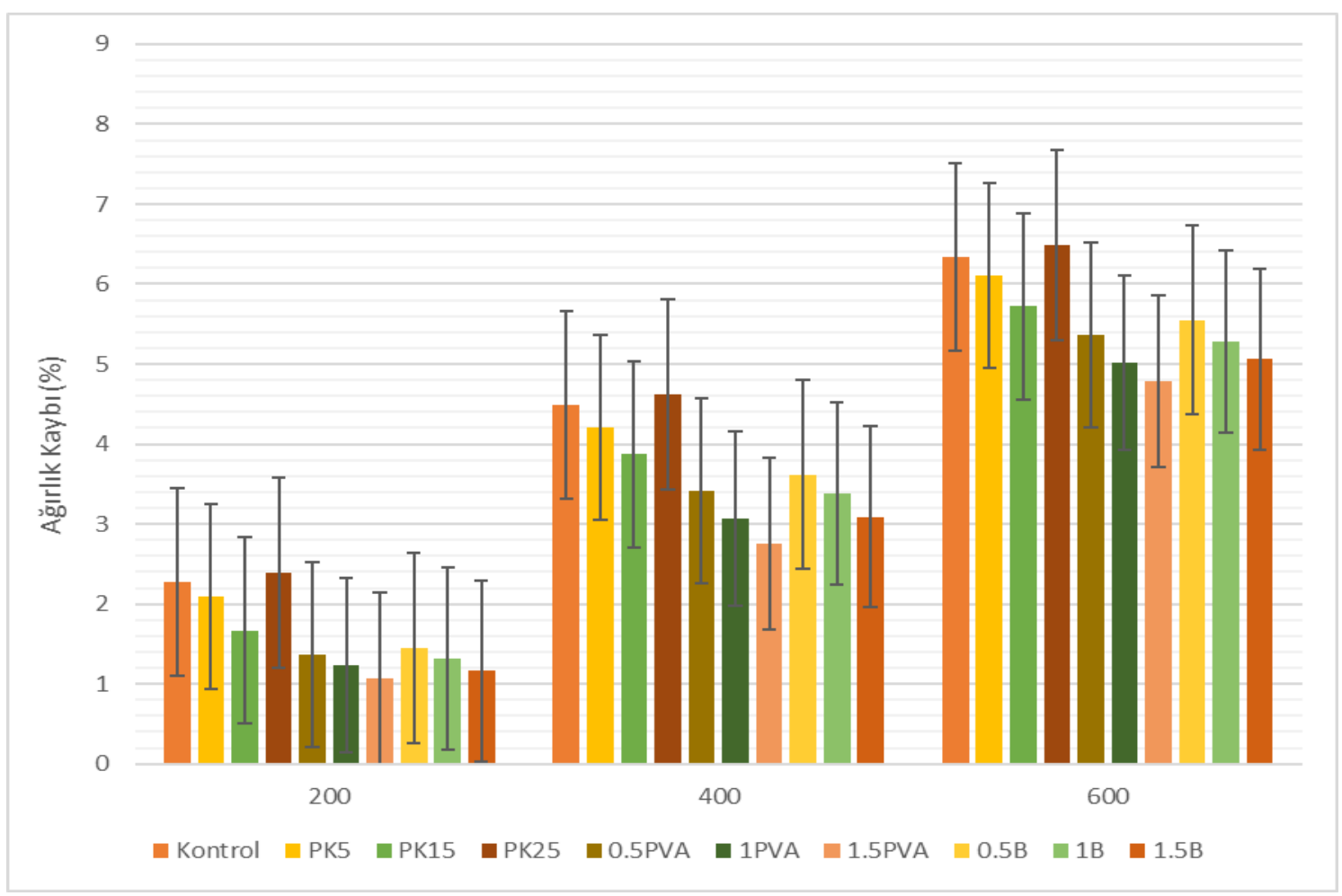

Şekil 5. Yüksek sıcaklık sonrası ağırlık kayıpları.

Yüksek sıcaklık etkisiyle dehidrasyon ve serbest su buharlaşması oluşur. Bu durum katı matriste hasara yol açar. Bunun yanında çatlaklarda genişleme ve matrislerde gözenek oluşur. Dehidrasyon etkisiyle matris yapısında bulunan nem yüzeye doğru hareket eder. Buna bağlı olarak mikroyapıda oluşan hasarlar ağırlık kaybını artırır. Yüksek sıcaklık etkisiyle öncelikle yapısal su ve serbest su kaybıyla ağırlık kaybı oluşur. Ağırlık kaybı temelde emilmiş, serbest ve kimyasal olarak bağlı suyun kaybından oluşur. Ağırlık kaybı $500^{\circ} \mathrm{C}$ 'den sonra önemli oranda artış gösterir. Bu ağırlık kaybında serbest suyun ve yoğunlaşmış hidroksil gruplarının buharlaşması rol oynamıştır [49-50]. İnce taneli pirinç kabuğu külünün \%15 oranına kadar reaksiyonu artırması ağırlık kaybını azaltmıştır. Daha yüksek oranda ise ağırlık kaybı artmıştır. Tüm sonuçlar değerlendirildiğinde, lifli numuneler için ağırlık kaybının daha az olduğu bulunmuştur. Böylelikle kullanılan liflerin etkisiyle ağırlı kaybında önemli bir azalma gözlemlenmiştir. $200^{\circ} \mathrm{C}$ sıcaklık sonrası ağırlık kayıpları \%1.07 ile \%2.39 arasında olurken $400^{\circ} \mathrm{C}$ sicaklık sonrası $\% 2.75$ ile $\% 4.62$ arasında olmuştur. $600^{\circ} \mathrm{C}$ sicaklık sonrası ise ağırlık kayıpları \%4.79 ile \%6.49 arasında olmuştur.

$600^{\circ} \mathrm{C}$ yüksek sıcaklık sonrası numunelerin yüzeyinde olan değişikler incelenmiş ve Şekil 6'da gösterilmiştir. Fotoğraftaki 1 numaralı çimento harcı kontrol serisi olup 2, 3 ve 4 numaralı çimento harçları sırasıyla PK5, PK10 ve PK15 serilerini göstermektedir. 
5, 6 ve 7 numaralı çimento harçları sırasıyla 0.5PVA, 1PVA ve 1.5PVA serilerini gösterirken 8,9 ve 10 numaralı çimento harçları sırasıyla $0.5 \mathrm{~B}, 1 \mathrm{~B}$ ve $1.5 \mathrm{~B}$ serilerini göstermektedir. Görsel inceleme, numuneler yüksek sıcaklık fırınından çıkarıldıktan 1 saat sonra yapılmıştır. Sıcaklık etkisi sonrası dayanım kayıpları oluşurken buna paralel bir biçimde renk değişimi de olmuştur. Numunelerde pürüzlülük artma eğilimi gösterirken daha kırılgan bir yapı oluşur. Bu durumu oluşturan temel sebep sıcaklıkla beraber C-S-H zincirlerinin zarar görmesidir. Numunelerde çatlakların oluşmasına rağmen stabilitenin korunduğu görülmüştür.

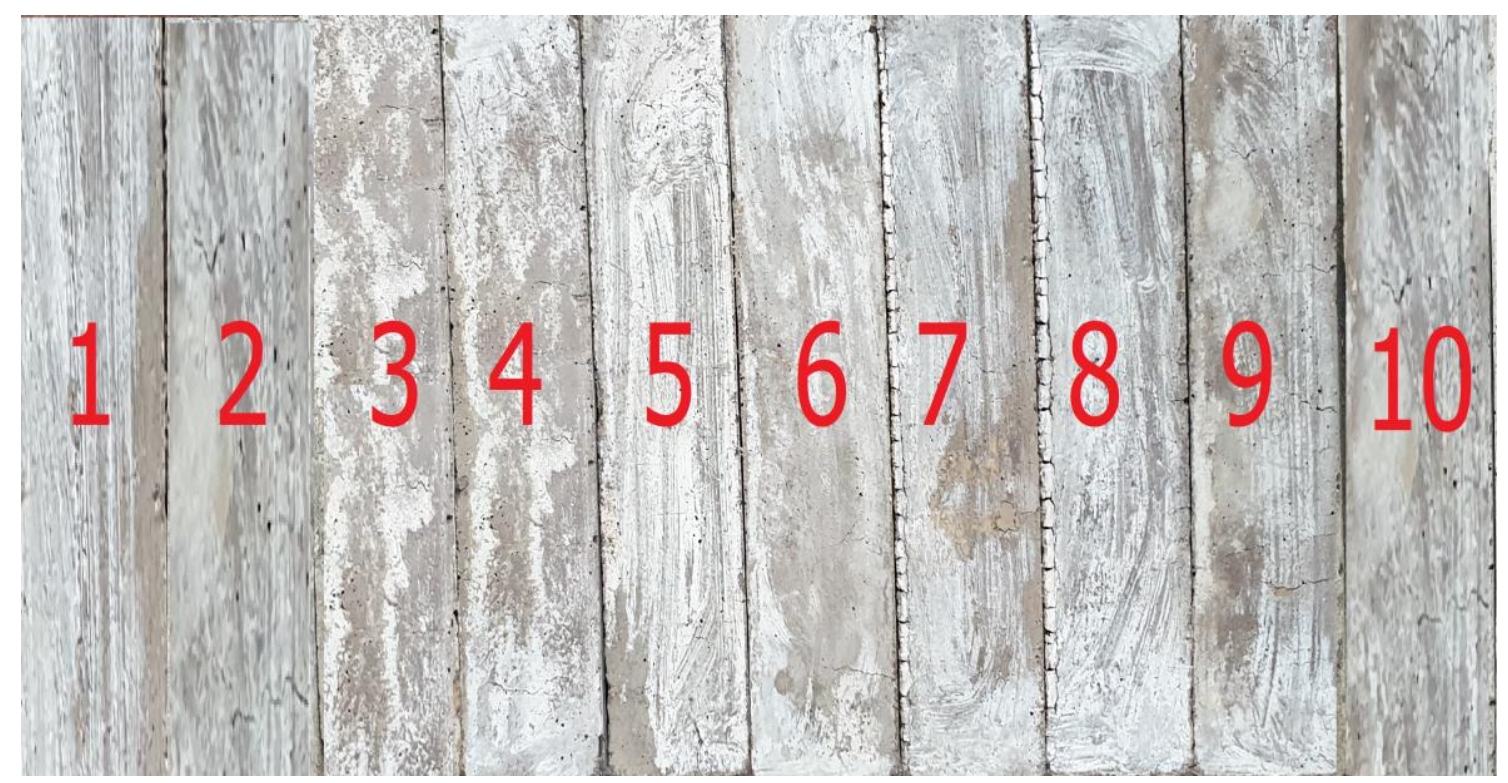

Şekil 6. Yüksek sıcaklık sonrası numunelerin görünümü.

PK15, 1PVA ve 1B çimento harçlarında 28 gün sonunda ve $600^{\circ} \mathrm{C}$ sıcaklık sonrası Micro-CT görüntüleri Şekil 7'de gösterilmiştir. Şekil 7, numunelerin temsili bir enine kesit görünümüdür. Kuruma büzülmesinden dolayı numunenin yüzey tarafinda küçük çatlaklar gözlenir. Ek olarak, numunedeki sıcaklık gradyanı, çatlak oluşumunun başka bir nedenidir. Özellikle su buharlaşmasının arttığı dönemde numunenin çekirdek bölgesinde dışarıya göre daha düşük bir sıcaklık oluşur. Bu nedenle çekirdek alandaki büzülme dış tabakaya göre daha azdır. Büzülmeler arasındaki bu uyumsuzluk çatlaklar yaratır. Ayrıca numunenin boyutu ve su içeriği çatlak oluşumunu tetikleyebilir. MicroCT görüntülerinde parlak renkler, yüksek X-ışını zayıflaması olan çakıl ve ince agrega gibi bileşenleri gösterirken, $\mathrm{X}$-ışını zayıflaması olmayan veya düşük olan bileşenler koyu renklerle (hava boşlukları) gösterilir. İç yapılardaki küçük çatlakların yanı sıra harçların morfolojik yapıları da yuvarlak gözeneklere sahiptir. Çatlak oluşumu açısından, 1PVA ve 1B çimento harçlarında lif etkisiyle daha az çatlak ve hava boşluğu oluşmuştur. PK15'te çatlak oluşumu daha fazla olmuştur [51]. 

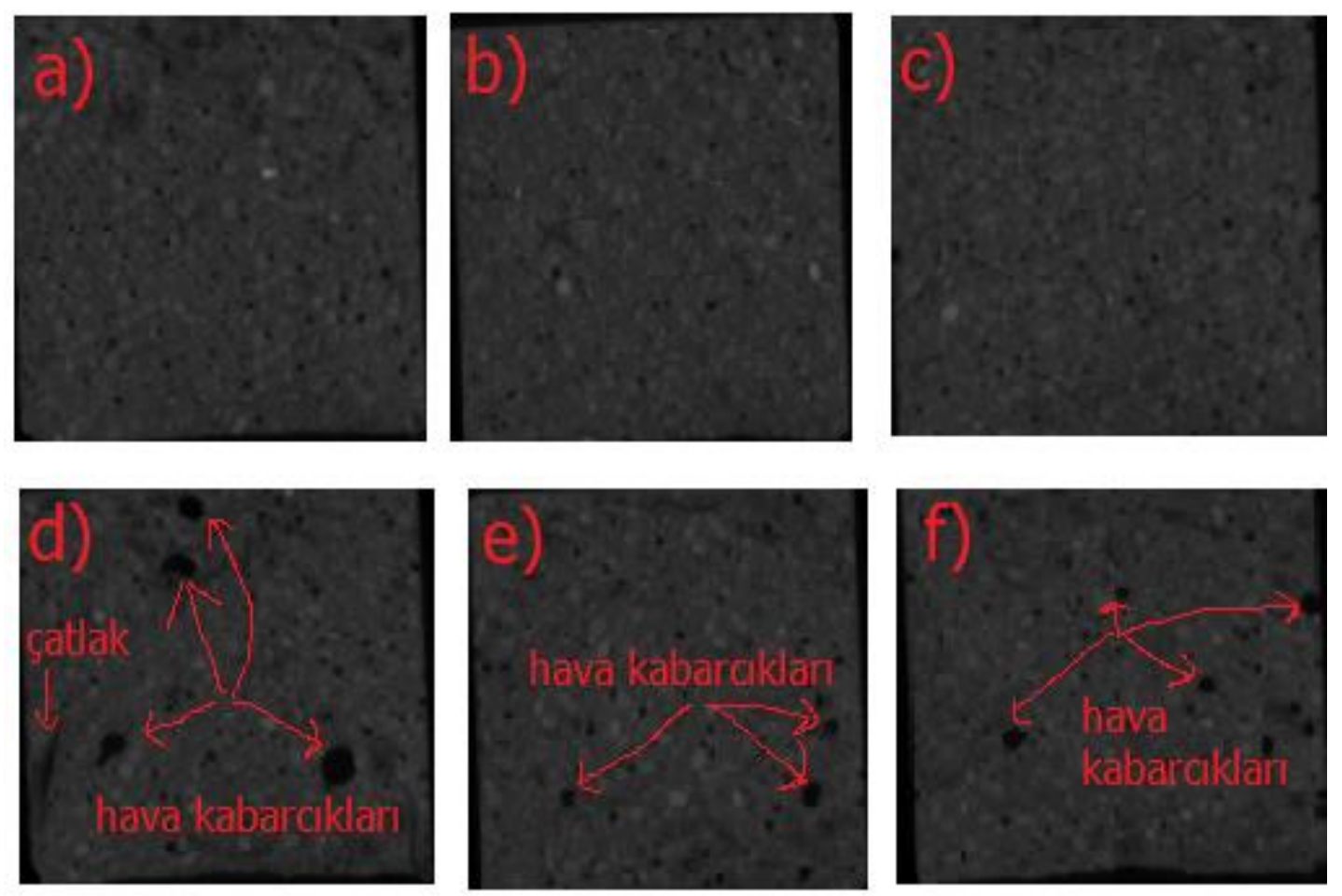

Şekil 7. Micro-CT görüntüleri a) 28 gün sonunda PK15 b) 28 gün sonunda 1PVA c) 28 gün sonunda $1 \mathrm{~B} \mathrm{~d}$ ) $600^{\circ} \mathrm{C}$ sonras1 $\mathrm{PK} 15$ e) $600^{\circ} \mathrm{C}$ sonras1 $1 \mathrm{PVA}$ f) $600^{\circ} \mathrm{C}$ sonras $1 \mathrm{~B}$

\section{Sonuçlar}

$\mathrm{Bu}$ çalışmada çimentolu harçların mekanik ve durabilite özellikleri analiz edilerek aşağıdaki sonuçlara ulaşılmıştır:

- Pirinç kabuğu külü \%15 oranına kadar dayanım sonuçlarında artış sağlamıştır. Özgül yüzey alanının yüksek olması kısa dönemde artış oluştururken yüksek $\mathrm{SiO}_{2}+\mathrm{Al}_{2} \mathrm{O}_{3}$ oranına $(\% 81.27)$ sahip olması uzun vadeli artış oluşturmuştur. Daha yüksek oranda ise işlenebilirliği azaltarak sonuçları düşürmüştür. Sonuçta pirinç kabuğu külünün Beyaz Çimentoyla birlikte kullanım açısından uyumlu bir puzolan olduğu görülmüştür.

- Liflerin \%1 oranında kullanılması basınç dayanımı sonuçlarını artırırken daha yüksek oranda kullanılmasıyla kümelenme ve düşük yoğunluk nedeniyle olumsuz etkilemiştir. Eğilme dayanımı sonuçları ise artan lif oranıyla sürekli artmıştır. PVA lifinin bazalt lifine göre daha yüksek çekme mukavemetine sahip olması daha sistematik performans göstermesini sağlamıştır.

- Yüksek sıcaklık etkisi sonrası basınç dayanımı sonuçlarında $200^{\circ} \mathrm{C}^{\prime}$ den sonra kuruma büzülmesi ve aderans gelişmesi nedeniyle artış olurken daha yüksek sıcaklıklarda matris yapısında bozulma nedeniyle azalış olmuştur. Pirinç kabuğu külünün boşlukları doldurması ve puzolanik reaksiyonu artırması yüksek sıcaklık sonrası da etkin olmuştur. Ağırlık kayıpları ise bozulma ile birlikte sürekli bir biçimde artmıştır. 


\section{Kaynaklar}

[1] Ozturk, A.U., Kaplan, G., A study of some durability properties of mortars with white cement and Portland cement, Revista Romana de Materiale-Romanian Journal of Materials, 47(3), 315-321, (2017).

[2] Jennings, H.M., Bullard, J.W., From electrons to infrastructure: Engineering concrete from the bottom up, Cement and Concrete Research, 41(7), 727-735, (2011).

[3] Bullard, J.W., Jennings, H.M., Livingston, R.A., Nonat, A., Scherer, G.W., Schweitzer, J.S., Scrivener, K.L., Thomas, J.J., Mechanisms of cement hydration, Cement and Concrete Research, 41(12), 1208-1223, (2011).

[4] Horsley, C., Emmert, M.H., Sakulich, A., Influence of alternative fuels on trace element content of ordinary portland cement, Fuel, 184, 481-489, (2016).

[5] Hamad, B.S., Investigations of chemical and physical properties of white cement concrete, Advanced Cement Based Materials, 2(4), 161-167, (1995).

[6] Fawzy, Y.A.G., Hay, A.S.A., Utilization of white cement in concrete mix containing srpc, Third International Conference, Advances in Civil, Structural and Mechanical Engineering, 71 - 75, Birmingham, (2015).

[7] Malhotra, V.M., Introduction: sustainable development and concrete technology, Concrete International, 24(7), (2002).

[8] Naik, T.R., Sustainability of concrete construction, Practice Periodical on Structural Design and Construction, 13(2), 98-103, (2008).

[9] Zerbino, R., Giaccio, G., Batic, O.R., Isaia, G.C., Alkali-silica reaction in mortars and concretes incorporating natural rice husk ash, Construction and Building Materials, 36, 796-806, (2012).

[10] Antiohos, S.K., Papadakis, V.G., Tsimas, S., Rice husk ash (RHA) effectiveness in cement and concrete as a function of reactive silica and fineness, Cement and Concrete Research, 61, 20-27, (2014).

[11] Kannan, V., Ganesan, K., Chloride and chemical resistance of self compacting concrete containing rice husk ash and Metakaolin, Construction and Building Materials, 51, 225-234, (2014).

[12] Gastaldini, A.L.G., Da Silva, M.P., Zamberlan, F.B., Neto, C.M., Total shrinkage, chloride penetration, and compressive strength of concretes that contain clear-colored rice husk ash, Construction and Building Materials, 54, 369-377, (2014).

[13] Zain, M.F.M., Islam, M.N., Mahmud, F., Jamil, M., Production of rice husk ash for use in concrete as a supplementary cementitious material, Construction and Building Materials, 25(2), 798-805, (2011).

[14] Chatveera, B., Lertwattanaruk, P., Durability of conventional concretes containing black rice husk ash, Journal of Environmental Management, 92(1), 59-66, (2011).

[15] Chao-Lung, H., Le Anh-Tuan, B., Chun-Tsun, C., Effect of rice husk ash on the strength and durability characteristics of concrete, Construction and Building Materials, 25(9), 3768-3772, (2011).

[16] Rößler, C., Bui, D.D., Ludwig, H.M., Rice husk ash as both pozzolanic admixture and internal curing agent in ultra-high performance concrete, Cement and Concrete Composites, 53, 270-278, (2014).

[17] Venkatanarayanan, H.K., Rangaraju, P.R., Effect of grinding of low-carbon rice husk ash on the microstructure and performance properties of blended cement concrete, Cement and Concrete Composites, 55, 348-363, (2015). 
[18] Praveenkumar, T.R., Vijayalakshmi, M.M., Meddah, M.S., Strengths and durability performances of blended cement concrete with $\mathrm{TiO}_{2}$ nanoparticles and rice husk ash, Construction and Building Materials, 217, 343-351, (2019).

[19] Jalal, A., Shafiq, N., Nikbakht, E., Kumar, R., Zahid, M., Mechanical properties of hybrid basalt-polyvinyl alcohol (PVA) fiber reinforced concrete, Key Engineering Materials, 744, 3-7, (2017).

[20] Choi, J.I., \& Lee, B.Y., Bonding properties of basalt fiber and strength reduction according to fiber orientation, Materials, 8(10), 6719-6727, (2015).

[21] Fan, F.L., Xu, J.Y., Bai, E.L., He, Q., Experimental study on impact-mechanics properties of basalt fibre reinforced concrete, Advanced Materials Research, 168, 1910-1914, (2011).

[22] Jiang, C., Fan, K., Wu, F., Chen, D., Experimental study on the mechanical properties and microstructure of chopped basalt fibre reinforced concrete, Materials \& Design, 58, 187-193, (2014).

[23] Ayub, T., Shafiq, N., Nuruddin, M.F., Effect of chopped basalt fibers on the mechanical properties and microstructure of high performance fiber reinforced concrete, Advances in Materials Science and Engineering, (2014).

[24] Hu, W., Yang, X.G., Zhou, J.W., Xing, H.G., Xiang, J., Experimental research on the mechanical properties of PVA fiber reinforced concrete, Research Journal of Applied Sciences, Engineering and Technology, 5(18), 45634567, (2013).

[25] Noushini, A., Samali, B., Vessalas, K., Flexural toughness and ductility characteristics of polyvinyl-alcohol fibre reinforced concrete (PVA-FRC), Proceedings of the 8th International Conference on Fracture Mechanics of Concrete and Concrete Structures, 1110-1121, Toledo, (2013).

[26] Annam, R., Study of Mechanical Properties of PVA Fiber-Reinforced Concrete With Raman Spectroscopic Analysis, Yüksek Lisans Tezi, Western Kentucky Üniversitesi, Kimya Bölümü Fakültesi, Kentucky, (2015).

[27] Olgun, Z., Pirinç kabuğu külünden magnezyum silikat üretimi ve üretilen magnezyum silikatların kızartma yağlarının rejenerasyonunda kullanılması, Yüksek Lisans Tezi, İstanbul Teknik Üniversitesi, Fen Bilimleri Enstitüsü, İstanbul, (2008).

[28] ASTM C109, Standard Test Method for Compressive Strength of Hydraulic Cement Mortars, ASTM International, West Conshohocken, PA, USA, (2016).

[29] ASTM C348-14, Standard Test Method for Flexural Strength of HydraulicCement Mortars, ASTM International, West Conshohocken, PA, USA, (2014).

[30] Ferraro, R.M., Nanni, A., Effect of off-white rice husk ash on strength, porosity, conductivity and corrosion resistance of white concrete, Construction and Building Materials, 31, 220-225, (2012).

[31] Tulashie, S.K., Kotoka, F., Mensah, D., Kwablah, A.K., Investigation of the compressive strength of pit sand, and sea sand mortar prisms produced with rice husk ash as additive, Construction and Building Materials, 151, 383-387, (2017).

[32] Sharma, R.K., Effect of substitution of cement with rice husk ash on compressive strength of concrete using plastic fibres and super plasticizer. KSCE Journal of Civil Engineering, 18(7), 2138-2142, (2014).

[33] Habeeb, G.A., Mahmud, H.B., Study on properties of rice husk ash and its use as cement replacement material, Materials Research, 13(2), 185-190, (2010). 
[34] Habib, A., Begum, R., Alam, M.M., Mechanical properties of synthetic fibers reinforced mortars, International Journal of Scientific \& Engineering Research, 4(4), 923-927, (2013).

[35] Sim, J., Park, C., Characteristics of basalt fiber as a strengthening material for concrete structures, Composites Part B: Engineering, 36(6-7), 504-512, (2005).

[36] Celik, A., Yilmaz, K., Canpolat, O., Al-Mashhadani, M.M., Aygörmez, Y., Uysal, M., High-temperature behavior and mechanical characteristics of boron waste additive metakaolin based geopolymer composites reinforced with synthetic fibers, Construction and Building Materials, 187, 1190-1203, (2018).

[37] Arslan, A.A., Uysal, M., Y1lmaz, A., Al-mashhadani, M.M., Canpolat, O., Şahin, F., Aygörmez, Y., Influence of wetting-drying curing system on the performance of fiber reinforced metakaolin-based geopolymer composites, Construction and Building Materials, 225, 909-926, (2019).

[38] Chindaprasirt, P., Chareerat, T., Sirivivatnanon, V., Workability and strength of coarse high calcium fly ash geopolymer, Cement and Concrete Composites, 29(3), 224-229, (2007).

[39] Spadea, S., Farina, I., Carrafiello, A., Fraternali, F., Recycled nylon fibers as cement mortar reinforcement, Construction and Building Materials, 80, 200209, (2015).

[40] Al-mashhadani, M.M., Canpolat, O., Aygörmez, Y., Uysal, M., Erdem, S., Mechanical and microstructural characterization of fiber reinforced fly ash based geopolymer composites, Construction and Building Materials, 167, 505-513, (2018).

[41] Kani, E.N., Allahverdi, A., Effects of curing time and temperature on strength development of inorganic polymeric binder based on natural pozzolan, Journal of Materials Science, 44(12), 3088-3097, (2009).

[42] Vijai, K., Kumutha, R., Vishnuram, B.G., Effect of types of curing on strength of geopolymer concrete, International Journal of Physical Sciences, 5(9), 1419-1423, (2010).

[43] Shinde, B.H., Kadam, K.N., , Properties of fly ash based geopolymer mortar with ambient curing, 2nd National Conference of Innovations in Civil Engineering, 203-206, (2016).

[44] Shaikh, F.U.A., Review of mechanical properties of short fibre reinforced geopolymer composites, Construction and Building Materials, 43, 37-49, (2013).

[45] Xu, F., Deng, X., Peng, C., Zhu, J., Chen, J., Mix design and flexural toughness of PVA fiber reinforced fly ash-geopolymer composites, Construction and Building Materials, 150, 179-189, (2017).

[46] Khan, M.Z.N., Hao, Y., Hao, H., Shaikh, F.U.A., Mechanical properties of ambient cured high strength hybrid steel and synthetic fibers reinforced geopolymer composites, Cement and Concrete Composites, 85, 133-152, (2018).

[47] Mechtcherine, V., de Andrade Silva, F., Müller, S., Jun, P., Toledo Filho, R.D., Coupled strain rate and temperature effects on the tensile behavior of strainhardening cement-based composites (SHCC) with PVA fibers, Cement and Concrete Research, 42(11), 1417-1427, (2012). 
[48] Wang, R., Meyer, C., Performance of cement mortar made with recycled high impact polystyrene, Cement and Concrete Composites, 34(9), 975-981, (2012).

[49] Heah, C.Y., Kamarudin, H., Al Bakri, A.M., Binhussain, M., Luqman, M., Nizar, I.K., Ruzaidi, C.M., Liew, Y.M., Effect of curing profile on kaolin-based geopolymers, Physics Procedia, 22, 305-311, (2011).

[50] Puertas, F., Martínez-Ramírez, S., Alonso, S., Vazquez, T., Alkali-activated fly ash/slag cements: strength behaviour and hydration products, Cement and Concrete Research, 30(10), 1625-1632, (2000).

[51] Aygörmez, Y., Canpolat, O., Al-mashhadani, M.M., Uysal, M., Elevated temperature, freezing-thawing and wetting-drying effects on polypropylene fiber reinforced metakaolin based geopolymer composites, Construction and Building Materials, 235, 117502, (2020). 